MARIEL AND THE POLITICS OF MEMORY

\title{
Memoirs of Sexile: Mariel Boatlift and the Cuban Queer Archives
}

\author{
Documentary-in-progress and artist statement
}

\author{
Lázaro González \\ University of California, Berkeley, US \\ lazaro.gonzalez@berkeley.edu
}

\begin{abstract}
Memoirs of Sexile: Mariel Boatlift and the Cuban Queer Archives is the repository of my ongoing documentary film Sexilio. This project seeks to build an archive of Cuban queer diasporic memory through oral history and analysis of various cultural texts, such as performances, poems, photos, and magazines. In addition to emphasizing the cultural resistance of the Cuban "sexiles," this article also traces my role as a participant subject in the act of collecting the queer exodus' memorabilia. My goal is to create a dialogue between several survivors of that "sexile" and the exodus's cultural memory that has survived through other materials such as René Valdés' papers, recently donated to the Tretter Collection of the University of Minnesota. Besides the inclusion of the oral history of several survivors of the exodus, whom I had been interviewing since 2015, my analysis will also highlight the lack of scholarship about the intersections between queer cinematographic archives, online archival practices, and digital humanities. In research and practice, these interdisciplinary fields could provide significant insights into the process of dealing with ephemeral materials. These methods seem to be the most appropriate to investigate what has been understood as the Cuban's sexile.
\end{abstract}

Keywords: Sexile; Queer Exodus; Archive; Mariel Exodus; Cuba; Documentary; Cuban Studies; Diaspora

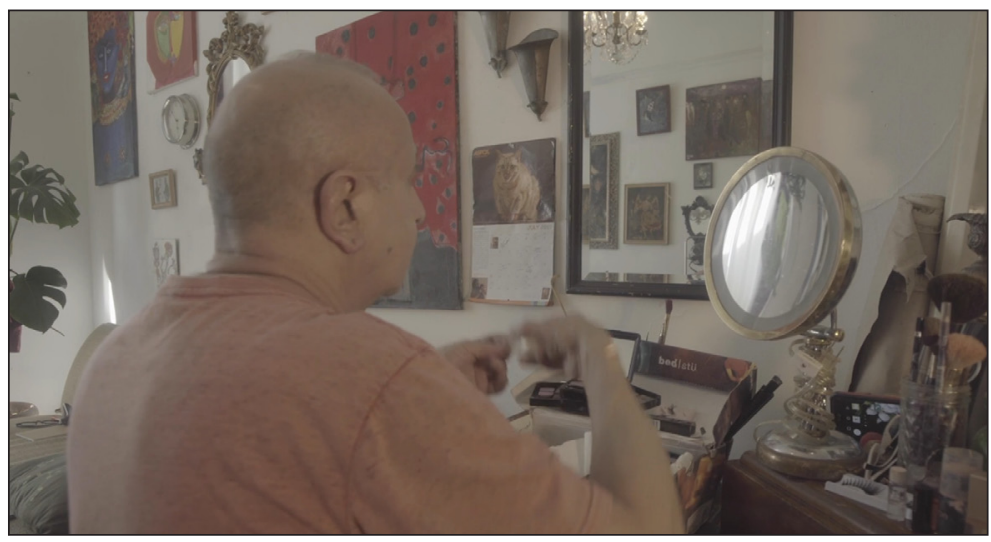

Trailer for Sexilio. Written, Directed, and Produced by Lazáro González, Encuadre Films.

I was in Minneapolis, lost within René Valdés' papers, when it began to snow. The flakes fell slowly, as if not wanting to interrupt the silence of the reading room. They were a subtle distraction, which accentuated my feeling of being in another time. I thought of the first time I saw a squirrel, right after taking a plane and leaving Cuba. I remember the animal's gracile movement, how she could climb the tree and hide before the lesser threat. I know that may seem naive because it is something I had seen in dozens of cartoon characters from my earliest childhood, but that was my reaction. Nonetheless, what matters here is how that archive was more about me than I had ever expected. 
In one of Renés photos from his first summer in Minneapolis, I found the same elusive squirrel that got caught up in my memory during a previous fall in Vermont when I met Eloy Guzmán, another queer "Marielito." Forty years ago, someone with a story very similar to mine had the same reaction. He never had the chance to talk to me, of course, but I perceived it in the photo that granted me access to his life. That flashy returned gaze to the camera was the queer gesture I was looking for. Nevertheless, that uncertainty between dream and reality, which only seems to be transgressed by the gracefulness of certain animals, is noticeable. It is the innocence of a present where there are still no deaths or bills to pay. The bucolic calm before chaos.

The awareness of that momentary happiness affected me. His photos of the first love appeared by surprise inside one of the boxes. The Cuban refugee was there naked, like a Greek god, photographed by that other who discovers him with desire. And then, both photographer and subject were switching turns or exposing themselves together in the frame, both undressed with the look and complicity of a camera that has no prejudice. A chiaroscuro where their hairs seem to intertwine, strokes of black and gold coincide in that timeless moment. It is still the summer of 1980, René has just left Fort McCoy, and no one can imagine that in the same box containing traces of a beautiful romance, news of a precocious death can also be found. Eros and Thanatos collapsing in the queer temporality of ephemera. That certainty of their vulnerabilities also affected me.

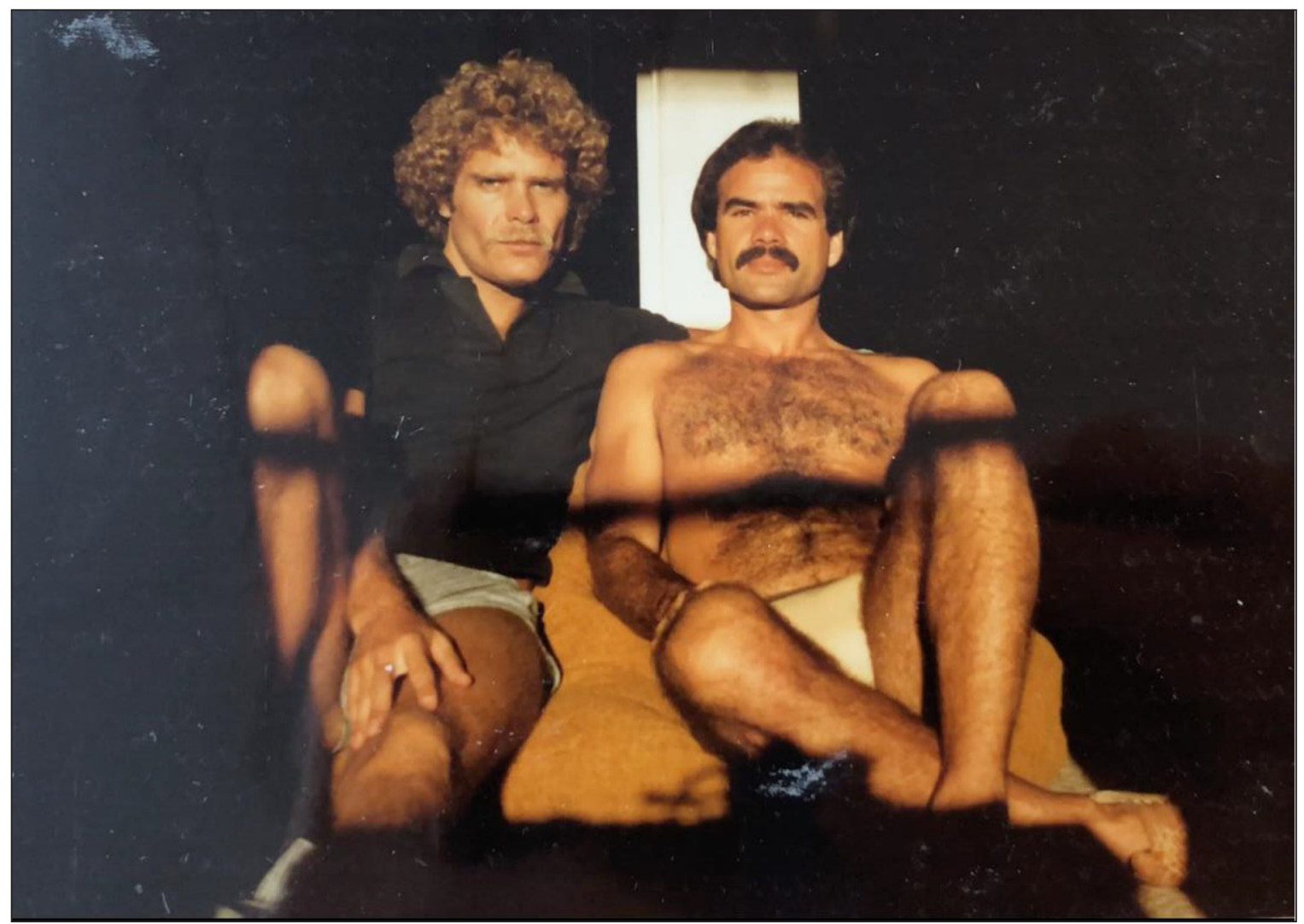

Photograph of René Valdés and (his partner) Bruce Brockway. 1980. René Valdés Papers. Jean Nickolaus Tretter Collection in LGBT Studies. Archives and Special Collections, Elmer L. Andersen Library, University of Minnesota, MN.

The discovery of René's archives, together with the testimonies of Eloy Guzmán, Nelson d' Alerta, Adela Vásquez, and many others, has been the engine behind Sexile's, attempt to create an archive of Cuban queer diaspora. I aim to permeate both the cinematographic text and the present essay that accompanies it with the same sense of search. This writing functions as a medium for the film and, at the same time, a repository of its absences, which for logistical or aesthetic reasons, cannot be within the confines of digital cinema. Both forms avoid conventional constructions and coincide in an essayistic desire.

The characters that can be seen in this film are not all those that I have interviewed over three years, but they are the ones that, in my opinion, can contribute the most to the narrative value of the film. They also denote very different memories of the traumatic experience that the Mariel Boatlift represented for Greater Cuba. Likewise, I have tried to relate my personal experiences to queer research methodologies that I had explored in Masks (2014) and Villa Rosa (2016). Both parts will have to fit together. Such organization of the argumentative corpus is also faithful to the performative structure of the film. It is consistent with a whole 
theoretical tradition on the limits of the archive and with queer research methodologies that also border on theories of non-fiction cinema.

For the film's creation, it was also crucial to attend to some of the theorists of the queer archive and their relationship with performative politics (Muñoz 2009; Cvetkovich 2003; Kumbier 2014). In this regard, queer archives are understood as space where one collects or cobbles historical understandings of sexuality and gender through an appraisal of presences and absences (Marshall et al 2). Similarly, I agree with the perspective of Alana Kumbier that, in the absence or disappearance of thematic or queer experiences from dominant discourses, researchers often create their archives by "conducting oral history interviews, assembling ephemeral material that circulated in LGBTQ communities, conducting ethnographic research through participant observation ... and 'auto-archiving,"' or writing personal memoirs to document queer histories (15).

These methods seem to be the most appropriate to investigate what I define as the "Cuban sexile." This migratory crisis has been seen as an abject page on Cuban history; therefore, it is difficult to access data segregated by race or sexual orientation. All these limitations, together with the need for evidence, symptomatic of traditional archival practices, also become an obstacle for the documentarians' tasks. This situation forces the filmmaker to assume a more participatory role. This is the case, for example, of Isaac Julien's Looking for Langston (1989) and Renate Costa's Cuchillo de Palo. 108 (2010). Both films share the same limitation: they want to create an homage to people who are not alive, and to do that, filmmakers must face the lack of the most common materials of social documentation. In this process, instead of seeking evidence, a desire to grasp what critics such as José Esteban Muñoz have identified as ephemeral emerges:

Ephemera includes traces of lived experience and performances of lived experience, maintaining experiential politics and urgencies long after these structures of feeling have been lived. Queerness, too, can be understood as a structure of feeling. Since queerness has not been let to stand, unassailed, in the mass public sphere, it has often existed and circulated as a shared structure of feeling that encompasses same-sex desire and other minoritarian sexualities but also holds other dissident affective relationships to different aspects of the sex/gender system. (Muñoz 11)

The ephemeral nature of these queer structures means that they are elusive, difficult to reproduce, or resistant to traditional methodologies. That is, they can be a more accessible text and, therefore, can satisfy this need, using creative solutions. I also integrate the notions of archive and repertoire raised by researcher Diana Taylor. From her perspective, the repertoire, as a more embodied praxis, goes beyond the limitations of traditional archives, which have a greater dependence on the written text. The repertoire acts as an embodied memory (performances, gestures, oral, movement, singing, dancing) and represents a fleeting and irreproducible knowledge (Taylor 56).

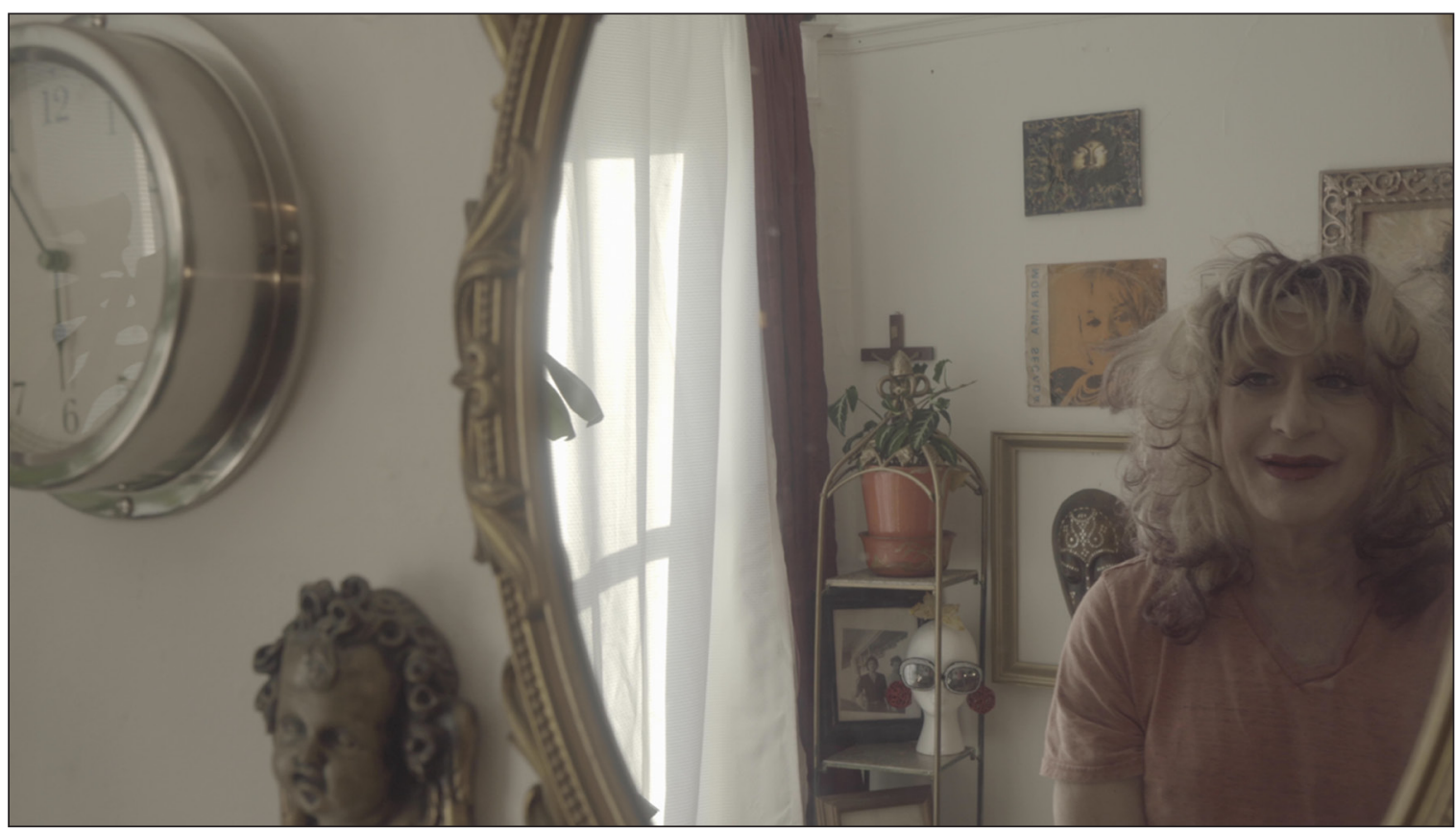

Still of Catherine White from Sexile. Written, directed, and produced by Lazáro González González. Encuadre Films. 
The process of Sexile has entailed the creation of an archive as well as a repertoire of Cuban queer diaspora. My approach has prioritized the mise en scène of irreproducible emotions or those feelings hard to transmit via the written text. Although the act of memory has been the primary mechanism, its performativization transcends any attempt at historicist reconstruction. The camera is focused on the emotions experienced by the documentary subjects while they interact with specific texts or stimuli created by the documentarian. These mediations also haunted me as a participating subject.

In this sense, the work with Nelson D'Alerta and his alter ego Catherine White has been vital. For example, in the reconstruction of their trauma resulting from homophobia in the educational context—during one interview when he speaks of how he was penalized by the desire to dance ballet—his gestures help us understand the reasons for his trauma. This is evidenced by Nelson representing with his hands when he secretly danced like a man on pointe in Havana. That nostalgic memory is performed—already through Catherine White-by showing a photo of Nelson dressed as a ballerina and with some quick dance steps in San Francisco. Such performances are beneficial to represent how queer acts were penalized during the 70s in Cuba. The mere description of this policing of non-heteronormative bodies would not have the same effect.

Although the video of a performance does not share the same degree of presence as when the performer/narrator is present in our space-time, I consider that there is greater organicity when the performance is created precisely for the cinematographic dispositive, which becomes the archive of that repertoire embodied by the protagonists. In this way, the recorded performance functions as a valuable source of knowledge. Diana Taylor also has pointed out how traumatic memory is often based on live performances (246). Following this logic, the act of giving testimony creates a connection between the victims and the witnesses, who in this case may be the filmmakers and, by transitivity, the spectators. Another common strategy is the use of photographs as a rhetorical device. This mechanism brings back subjects erased by history. She identifies this trace as the performance's DNA, making it possible to link performative and scientific demands (250). ${ }^{1}$

That trace is similar to the space of memory stimulated when documentary subjects reveal to the recording device, for example, the pictures of their dead friends. Such an act presents people missing or absent as it helps evoke the trauma's memory. For Sexile, the constant interaction with photographs by the characters and the director activates a repertoire of ephemeral experiences related to sexual dissidence and constitutes evidence of identity. This approach makes it possible to blur the boundaries between individual and collective experience, in a process in which living sources can coincide with those who are no longer here but who do not cease to exist in memory.

\section{Mariel's Queer Exodus}

The memory of the Mariel exodus, though a forbidden topic for official Cuban historiography, persists. From a queer perspective, not enough research has been done outside of Cuba either. As a result, the process of searching for these hidden memories must be considered as part of the archive. The exodus's most representative oeuvres are the essays compiled in Reinaldo Arenas's Necesidad de libertad (1986) and his autobiographical novel Before Night Falls (1992). However, these texts are not sufficient to understand the complexities of the migratory phenomenon.

Likewise, I consider it more relevant for this essay, the short story "Final de un cuento," published in the first issue of the magazine Mariel in 1983. Although there is no explicit identification with an LGBTQI "Marielito" figure, it is easy to discern in the following fragment a poetic reference to them:

Por última vez, esto que somos, [sic] se habrá de confundir, mezclándonos uno en el otro ... Ahora, iadiós! A volar, a navegar. Así. Que las aguas te tomen, te impulsen y te lleven de regreso ... Mar de los sargazos, mar tenebroso, divino mar, acepta mi tesoro; no rechaces las cenizas de mi amigo; así como tantas veces allá abajo te rogamos los dos, desesperados y enfurecidos, que nos trajeses a este sitio y lo hiciste, llévatelo ahora a él a la otra orilla, deposítalo suavemente en el lugar que tanto odió, donde tanto lo jodieron, de donde salió huyendo y lejos del cual no pudo seguir viviendo. (Arenas 82-83)

Arenas' text could be read as a manifesto about the importance of preserving the memory of those banished from their countries and the desire to return to the native land through an act of memory. In this way, they are building a queer utopia, altogether with an archive of feelings. The narration highlights a concern that marked many of Eloy Guzmán's friends, who could not return to Cuba alive. The figure of queer "Marielitos" has recently been represented in Alan Lessik's novel The Troubleseeker (2016). This text, inspired by the life

\footnotetext{
${ }^{1}$ According to Taylor, the DNA of the performance "feeds two systems heuristics, not only of the biological and performative, but also archive and repertoire" (253).
} 
of the Cuban René Valdés, narrates the odyssey of Antinio, who is facing their identity as gay in the postrevolutionary Cuba and as a refugee in the United States. All these fictions, and the crucial scholarship of Susana Peña and Julio Capó, consider this migratory process as a perfect chance to justify the purge of undesirable subjects for the socialist project. ${ }^{2}$ Among these were, of course, the homosexuals, who were alien to the idea of the Cuban Revolution's hombre nuevo (new man).

Many acts of institutional homophobia before Mariel's sexile can be considered as direct antecedents of this phenomenon. Perhaps the most significant example is the creation of Military Units in Support of Production (UMAP), a sort of concentration camps where about 35,000 gay and religious people-primarily young males of military age - were confined in 1965. In addition, after the closure of these units, the discrimination continued in other ways. A year before the immigration crisis, the public scandal law of 1936 was updated, adding the term "antisocial behavior" and an increase from six to nine months for the maximum penalty for this crime. All these actions, combined with the expulsion by force of queer people like Eloy Guzmán, demonstrate how the government criminalized queer expressions. So, the legal migration through the port of Mariel served as an escape valve and culmination of several decades of institutionalized homophobia and its deployment by repression, imprisonment, labor restrictions, and social discredit. Although it is hard to estimate the number of homosexuals who escaped from the port of Mariel, as Ian Lumsden affirms, "they were numerous enough to be singled out as targets in the mass demonstrations directed against those who opt to leave" (78).

\section{Identification Issues and Media Stigmatization}

It is necessary to remember that in 1980, U.S. laws excluded queer immigrants. Indeed, the arrival of a significant number of Cuban homosexuals was problematic for the U.S. However, the identification of gay Cubans by part of the U.S. gaze was inconsistent and full of contradictions. Susana Peña delineates this challenge:

Homosexual Cuban immigrants, ostentatious ones at that, presented three significant complications for this receiving nation. First, homosexual Cubans embodied many of the existing contradictions and ambiguities of U.S. immigration policies governing homosexuals and Cubans as separate categories. Second, the identification of Cuban homosexuals was complicated because Mariel Cubans were processed differently by a number of federal, state, local, and voluntary agencies (VOLAGs) in a range of locations throughout the United States. These bureaucratic and jurisdictional differences inevitably led to disparate identification procedures. Third, the flood of national media attention that enveloped Mariel further complicated such procedures. (491)

What is paradoxical is that, in Cuba, homosexuals were forced to ostent their homosexuality in order to get out of the country, and then they had to camouflage it in the U.S. because such identification was problematic for immigration authorities. The Immigration and Naturalization Service (INS) used to forbid the entry of those identified as gays. Nevertheless, they had to make an exception for the Cubans. However, it was not until September 1980, almost at the end of the exodus, that the INS rectified its policy of exclusion. Therefore, it can be deduced that they felt the need to clarify their mechanisms in order to deal with the sudden flow of migration as well as with the increase of the media's interest in the Cuban gay migrants (Peña 57).

With such uncertainty involved in migration, it is also hard to collect evidence on how U.S. officials formally identified, enumerated, or processed queer "Marielitos" in a way different from heteronormative subjects. However, recent cultural texts as The Troubleseeker also refer to the consequences of proving one's gay identity before emigration authorities. In this case, Antinio, the protagonist of the novel, had to wait more than ten years to receive his green card after confessing to the interviewer why he was expelled from Cuba. René Valdés, the person behind the character of Antinio, kept all the documents related to this process and they are available now in the Tretter Collection of the University of Minnesota Library. These materials are of utmost importance for the present research because they testify to one of the most challenging processes for a queer diasporic subject.

Although it is impossible to rely on the protagonist's presence, his archive proves how the INS's homophobia complicated René's naturalization. A slight trace of his emotions has been impregnated in his notes to the official letters and in some fragments of his diaries. Similarly, Nelson D'Alerta's testimony confirmed that INS officials also asked questions about sexual orientation. Immigration officers inquired about his sexual practices and wrote the word "homosexual" in the folder of his immigration case. D'Alerta's honest response caused the same delay that René Valdés suffered in being granted permanent residency.

\footnotetext{
${ }^{2}$ Within the North American academic context, there are few studies focused on the Cuban queer diaspora. Oye Loca: From the Mariel Boatlift to Gay Cuban Miami (2013), by Susana Peña, and Queering Mariel, by Julio Capó Jr., constitute perhaps the most influential scholarship published by a U.S. academic press on this topic.
} 


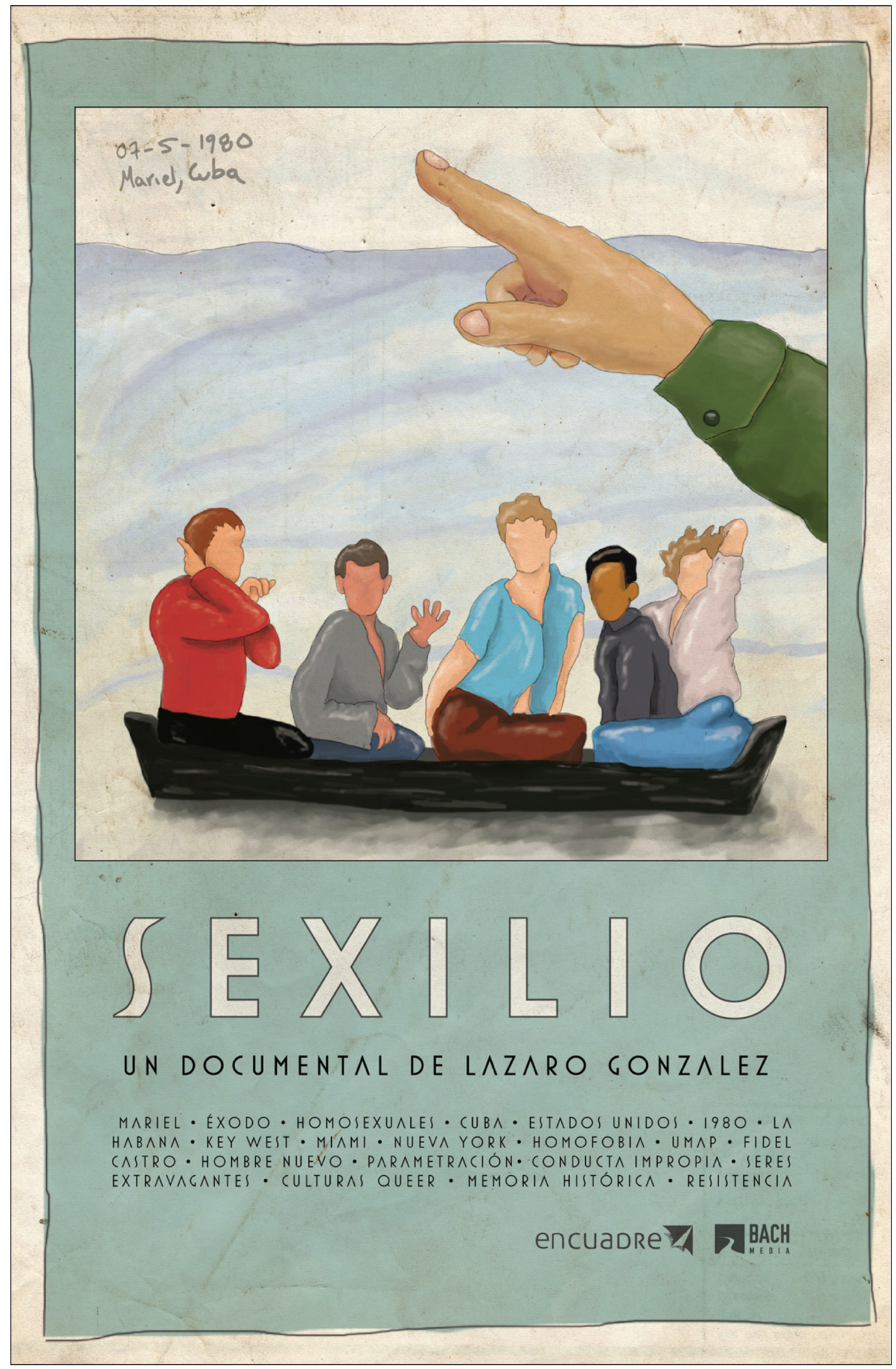

"Poster of Sexile" from: Nidal Koteich. Written, directed, and produced by Lazáro González González. Encuadre Films. 


\section{The Resettlement Camps}

One of the most traumatic experiences that affected Cuban sexiles was the resettlement process. Because of a lack of sponsorship, many "Marielitos" were sent to tents under Miami's highways or resettlement camps in other states. In some cases, they went to Eglin Air Force Base, Florida; Fort Indiantown Gap, Pennsylvania; Fort Chaffee, Arkansas; and Fort McCoy, Wisconsin, without even knowing about it. As Omar Granados acknowledges, "very few works have dealt with the fraught months many "Marielitos" spent at refugee camps" (2). From his perspective, further analysis of what happened on these sites can help reconstruct historical memory and build the exodus's geopolitics (3). I would add to this experience the need to explore how these camps must have triggered memories of the UMAP for those who suffered it.

Furthermore, the "fear" of "Marielitos" was not only because they represented economically deprived sectors of society or because there were people with mental illnesses, felons, and prominent homosexuals. Many of them seemed to be phenotypically darker than the norm in South Florida. Without a doubt, one of the gaps opened by the exodus of the Mariel was the creation of a myth of racial difference between the two shores of cubanidad: Cuba and Miami. Alejandro de la Fuente also mentions that "the Marielitos sociodemographic composition threatened to undermine the representation of Miami as the social, racial, and political antithesis of revolutionary Cuba. Havana responded by depicting them as escoria, the scum of Cuba's socialism. Revolutionary Cuba could not afford to have a nonwhite, nonelitist Miami" (305).

In other words, the Cuban "Marielito," more so those who were black and LGBTQI, suffered a crossfire from the island and its diaspora. Instead of offering shelter to new arrivals, many in the Cuban American community rejected them as much as the Cuban government did. Moreover, these prejudices made their assimilation more difficult. Eloy recalls how a Cuban American lady in Miami had said that resettlement was slow because too many black people came in the exodus.

In terms of the experience of those who lacked a sponsor, perhaps the only audiovisual piece addressing this topic is Miñuca Villaverde's Tent City (1980). ${ }^{3}$ This documentary focuses on locas living under a Miami expressway that turned into a visible space for queer lives. Tent City is striking because of its intersectional attention to race, sex, and gender as factors that contributed to the sexiles' construction as abject subjects. By speaking in voiceover, the director denounces how many of her subjects are on that site because their relatives in Miami did not accept them. These testimonies, mixed with the evident representation of the queer desire for liberation, are one of this piece's most relevant achievements.

Freedom Town/Tent City represents what the state and Cuban Americans enacted in the shadows. In these sites, the sexiles auto-segregated themselves, which facilitated press coverage about this group but hindered its inclusion even more when they were transgender or more visibly gay. In one article from The Washington Post published in July 1980, the authors informed that about 20,000 homosexuals were waiting for relocation. Immediately, the institutions in charge of this process denied that number and argued that some had been misidentified as gay (Peña 47). This inability to quantify, adds Peña, "facilitated the silence on this matter in the media. By drawing attention to quantitative failures, the federal authorities helped keep veiled and full of uncertainty the potentially explosive queer history of the Mariel" (57). However, traces of queer memory can still be found in ephemeral materials, recollected in major cities where the "Marielitos" resettled such as Miami, Philadelphia, San Francisco, and Minneapolis. That ephemera has been crucial to my research although my search for queer diasporic memory, as I explained, does not have a quantitative intention.

On the other hand, several activists and LGBTQI organizations of the United States tried to support the queer refugees, making visible the helplessness of those not getting sponsorship. The best example of this communion of interests (which has been scantily little documented to date) can be found in Minnesota, where local activists created the Positively Gay Cuban Refugee Task Force to "rescue" Cubans held at Fort McCoy because they were not able to find sponsors. The initiative, developed by Thom Higgins and Bruce Brockway, helped the resettlement of about ninety "Marielitos," including René Valdés, who fell in love with one of the activists. Unfortunately, Brockway died a few years later. ${ }^{4}$ A significant part of the archive I will put on display pays homage to their romance. This archive of feelings also proves how the U.S. LGBTQI activism was aware of the INS's exclusionary policies and the masquerades gay refugees were forced to perform in exchange for a safe path to naturalization. Thanks to the work of the Cuban Refugee Task Force, there exists some evidence of these actions. So far, a listing with the names and other information about the "Marielitos" they were able to help is perhaps the most compelling ephemeral material that illuminates my archiveological desire.

\footnotetext{
${ }^{3}$ It is, along with Orlando Jiménez Leal and Nestor Almendros' Improper Conduct (1984), and Manuel Zayas' Seres extravagantes (2004), part of the few filmic productions focusing to some extent on Mariel's diasporic queer subjectivities.

${ }^{4}$ He was also the first person to die of AIDS in Minnesota.
} 


\section{The Ephemeral Queer Footprint in Other Areas}

I could not find more visible documentation of resettlement efforts in Philadelphia, San Francisco, or Miami, even though there are enough references to how these cities were also very welcoming. For example, the Metropolitan Community Church in Philadelphia assisted in the processing of sexiles' coming out of Fort Indiantown Gap, and several newspapers covered their resettlement in the Bay Area. In one of these publications, The Sentinel, there are references to the aid of some organizations, and it also addresses San Francisco's preparation for the arrival of many Cuban homosexuals. According to the news, they had created a Gay and Lesbian Cuban Refugee Program under the sponsorship of the Metropolitan Community Church in that city (5).

In addition to media coverage, personal archives offer some documentation about the influence of those queer refugees in Latinx communities in cities such as San Francisco. The epitome of this cultural encounter can be found in Nelson D'Alerta drag performances. He moved to this city after a few months in Miami and Dallas. On the West Coast, his alter ego Catherine White became the star of a local Hispanic television show. The vast majority of these television broadcasts have been preserved on VHS by D'Alerta and will be gradually digitized as soon as he has the resources to do so. More specifically, the social impact of Cuban queer immigrants in San Francisco can be appreciated in the videotape recording of the play La Casa de Bernalda Alba, performed at the Mission Cultural Center for Latino Arts. D'Alerta directed this play, and all the performers were Mariel queer refugees, such as Adela Vázquez and Sophia Lamar. For Nelson, who had come out of Cuba with the dream of making theater, that was one of the most rewarding opportunities of his life in exile. In addition, Catherine White found pleasure in paying homage, from the stage, to those who escaped communism but did not survive AIDS. $^{5}$

On my way to constructing an archive of Cuban sexile, the point of departure has been the act of memory represented by my documentary subjects, together with my immersion in the available archives. These methodologies still leave plenty of uncertainties and absences. I have tried to fill the gaps with this collage of testimonial inquiry and dialogue with fictional narratives. In this direction, Alana Kumbier, Diana Taylor and José Esteban Muñoz helped me find performative strategies to represent archives of feelings.

Similarly, I did an exhaustive analysis of various newspapers and other ephemera in Cuba and the United States. I conceived of this essay as a diary of my research. My approach as a filmmaker and researcher also seeks to alleviate those areas of silence. From my perspective, the act of listening to the cultural legacy of the Cuban queer diaspora demands an intergenerational and transnational dialogue. In other words, the encounter between two subjects, the one who wants to write and the other who wants to film, is a pretext to be able to enter a greater universe. It is about the mapping of an exodus and its complexities.

Nonetheless, many questions still remain. To name a few: how to recover the memory of those who can no longer speak? What to do when certain subjects are not aware of having suffered racial or sexual discrimination? What are the most effective strategies for acknowledging "Marielitos" cultural legacy? All these questions belong to an archiveological desire that is willing to be a living corpus, varied as the migratory experiences, and fundamentally open to the inclusion of new voices. A closed structure and too many theoretical ambitions would run entirely against my intentions. For this reason, I prefer to think of this text as something unfinished, exposed to the constant rewriting of the past.

The film will go the same way, growing in length and in testimonies that help to show one view that is more plural than what the exodus meant to them. Cinema cannot kill the archive-Cinema expands it; it provokes the opening of new temporalities where the memories of those who are no longer here can converge with those who continue to invoke their disappeared. In that time and in that space, we will continue talking about sexiles.

\section{Competing Interests}

The author has no competing interests to declare.

\footnotetext{
${ }^{5}$ See recording of La casa de Bernalda Alba (1995) from Nelson D'Alerta's personal archives: https://vimeo.com/613041169.
} 


\section{References}

Arenas, Reinaldo. "Final de un cuento." Llópiz Cudel, Jorge Luis. Los cuentos de la revista Mariel. Editorial Nosotros, 2016.

Capó, Julio Jr. "Queering Mariel: Mediating Cold War Foreign Policy and U.S. Citizenship among Cuba's Homosexual Exile Community, 1978-1994." Immigrant Identity and the Politics of Citizenship, edited by John J. Bukowczyk, University of Illinois Press, 2016, pp. 268-296.

de la Fuente, Alejandro. A Nation for All. Race, Inequality, and Politics in Twentieth Century Cuba. U North Carolina P, 2001.

Higgins, Thom L. Thom Higgins Papers. Cuban Refugess, 1980, 1990. Archival material. Minnesotta Historical Society, 1980.

Kerby, Chris. "Gays Launch Efforts To Help Cuban Refugees." The Sentinel 11 July, 1980, pp. 1-4.

Koteich, Nidal. "Poster of Sexile." Written, directed, and produced by Lazáro González González. Encuadre Films.

Marshall, Daniel. et al. "Editors' Introduction: Queering Archives: Historical Unravelings." Radical History Review, no. 120, 2014, pp. 1-11. DOI: https://doi.org/10.1215/01636545-2703706

Muñoz, José Esteban. Cruising Utopia: The Then and There of Queer Futurity. New York U P, 2009.

Muñoz, José Esteban. "Ephemera as Evidence: Introductory Notes to Queer Acts." Women \& Performance, vo. 8, no. 2, 1996, pp. 5-16. DOI: https://doi.org/10.1080/07407709608571228

Peña, Susana. "'Obvious Gays' and the State Gaze: Cuban Gay Visibility and U.S. Immigration Policy During the 1980 Mariel Boatlift." Journal of the History of Sexuality, vo. 16, no. 3, 2007, pp. 482-514. DOI: https://doi.org/10.1353/sex.2007.0072

---. iOye Loca!: From the Mariel Boatlift to Gay Cuban Miami. U Minnesota P, 2013.

Taylor, Diana. El archivo y el repertorio. La memoria cultural performática en las Américas. Ediciones Universidad Alberto Hurtado, 2015.

How to cite this article: González, L 2021 Memoirs of Sexile: Mariel Boatlift and the Cuban Queer Archives. Anthurium, 17(2): 11, 1-9. DOI: https://doi.org/10.33596/anth.453

Published: 14 December 2021

Copyright: ( $) 2021$ The Author(s). This is an open-access article distributed under the terms of the Creative Commons Attribution 4.0 International License (CC-BY 4.0), which permits unrestricted use, distribution, and reproduction in any medium, provided the original author and source are credited. See http://creativecommons.org/licenses/by/4.0/. 